\title{
¿Pacificación o revancha? Derechos humanos, oposición y dictadura en la revista peronista Línea (1980-1983)
}

\section{Pacification or Retaliation? Human Rights, Opposition, and Dictatorship in the Peronist Magazine Línea (1980-1983)}

\author{
Eduardo Raíces* \\ (D) https://orcid.org/0000-0001-6299-0968 \\ Facultad de Ciencias Sociales \\ Universidad de Buenos Aires, Argentina \\ e_raices@hotmail.com
}

Resumen: Este artículo aborda el tratamiento de los derechos humanos en la revista peronista opositora Línea, surgida durante última dictadura argentina, mediante el análisis de las ediciones publicadas en el periodo. Se trata de una aproximación no trabajada anteriormente dentro de la literatura académica. Para tal efecto, revisamos artículos, editoriales, humor gráfico y una entrevista al entonces flamante Nobel de la Paz, Adolfo Pérez Esquivel. Las conclusiones subrayan la influencia en sus definiciones del sostenimiento de

* Investigador de apoyo del proyecto PICT 201-0063 "Las revistas políticas argentinas en la encrucijada nacional: del peronismo al golpe (1973-1976)", dirigido por el doctor Marcelo Borrelli. Facultad de Ciencias Sociales, Universidad de Buenos Aires, programación 2018-2021. Agradezco los comentarios de los evaluadores anónimos del presente artículo.

cómo citar: Raíces, E. (2020). ¿Pacificación o revancha? Derechos humanos, oposición y dictadura en la revista peronista Línea (1980-1983). Secuencia (108), e1733. Dor: https://doi.org/10.18234/secuencia. v0i108.1733

\section{c) 98}

Esta obra está protegida bajo una Licencia Creative Commons Atribución-NoComercial 4.0 Internacional. 
la legitimidad del gobierno constitucional justicialista derrocado en 1976, incluida su faceta represiva y, a la vez, de la crítica a las políticas económicas dictatoriales que habían afectado fuertemente las bases sociales del peronismo. Asimismo, que Línea aborda las desapariciones forzadas de personas entre la discusión sobre su "culpabilidad" o "inocencia" y las sospechas ante un movimiento de derechos humanos con articulaciones internacionales en el marco de la guerra fría.

Palabras clave: Argentina; prensa gráfica; peronismo; dictadura militar (19761983); derechos humanos.

Abstract: The article addresses the handling of human rights in the peronist opposition magazine Linea, which emerged during the last Argentine dictatorship, by analyzing the issues published during this period. This approach has not previously been explored in the academic literature. To this end, we examine articles, editorials, graphic humor, and an interview with the then recent Nobel Peace prize laureate Adolfo Pérez Esquivel. The conclusions underline the influence in his definitions of the support of the legitimacy of the justicialist constitutional government overthrown in 1976, including its repressive facet and, at the same time, of the criticism of dictatorial economic and social policies that had strongly affected the social bases of peronism. They also explore the fact that Linea addressed forced disappearances amid the discussion about the "guilt" and "innocence" of the victims and the suspicions towards a human rights movement with international links within the cold war framework.

Keywords: Argentina; graphic press; peronism; military dictatorship (19761983); human rights.

Recibido: 29 de marzo de 2019 Aceptado: 19 de agosto de 2019 Publicado: 28 de julio de 2020 


\section{INTRODUCCIÓN}

T a presente contribución analiza el abordaje de los derechos humanos en la Lrevista Línea durante la última dictadura militar argentina, denominada "Proceso de Reorganización Nacional" (1976-1983). Esta publicación de ideología peronista transitó la "apertura política" del régimen generada por la crisis económica, su conflictividad interna y la rearticulación política opositora, que llevaría a los principales actores políticos a formar la Multipartidaria. Como consecuencia de su repercusión y ventas, Línea sufrió el secuestro de ediciones, la prohibición de su circulación en algunas provincias y el procesamiento judicial de su director, promovidos por las autoridades de facto.

En ese marco, Línea tematizó de modo peculiar las violaciones a los derechos humanos. En adelante daremos cuenta de cómo abordó este tema en distintas ediciones, analizando los editoriales y determinados textos, escritos y visuales. El corpus subsiguiente abarca de los números 1 al 48, marcando este último las elecciones presidenciales de 1983, que señalan el fin de la dictadura. En particular, daremos relevancia a una entrevista al entonces flamante premio Nobel de la Paz, Adolfo Pérez Esquivel, coordinador del organismo de derechos humanos Servicio Paz y Justicia (SERPAJ), por la significación coyuntural del acontecimiento.

Esta selección nos permitirá, primero, establecer la concepción de la revista sobre la desaparición forzada de personas y el terrorismo de Estado como problemas sociales. En segundo lugar, observar su posición respecto al movimiento de derechos humanos y, en especial, a la premiación de Pérez Esquivel. Por último, relacionar las interpretaciones de la revista con la coyuntura política.

$\mathrm{Al}$ respecto, las concepciones de Línea se asociarán con los pronunciamientos públicos del Partido Justicialista (PJ) en la materia y con los de la Multipartidaria, organización que el PJ integró durante el periodo contemplado en este artículo. ${ }^{1}$

En suma, estudiaremos las nociones sobre los derechos humanos y el terrorismo de Estado elaboradas durante la última dictadura desde el discur-

${ }^{1}$ La Multipartidaria se conformó a mediados de 1981 para ejercer una oposición moderada al gobierno militar y negociar condiciones de retorno al régimen democrático. Se disolvió con las elecciones presidenciales de 1983. Estuvo integrada, además del PJ, por la Unión Cívica Radical, el Movimiento de Integración y Desarrollo, el Partido Demócrata Cristiano, y otros. Véase Novaro y Palermo (2003, pp. 372-384). 
so peronista, tal como fueron reflejadas en Línea. Estas elaboraciones, relacionadas con uno de los actores fundamentales del espectro político de la época, no han recibido una atención apreciable en la literatura testimonial y académica posdictatorial, y pretendemos en lo que sigue contribuir a subsanar esa ausencia.

\section{LÍNEA: REARTICULACIÓN DEL JUSTICIALISMO Y OPOSICIÓN A LA DICTADURA}

Línea lanzó su edición inicial en junio de 1980 y su existencia se extendió hasta principios de la década siguiente. Se trataba de una publicación mensual de actualidad política con distribución nacional destinada a un público amplio de identificación peronista. Fue dirigida por el veterano intelectual José María "Pepe" Rosa ${ }^{2}$ y contó con un nutrido staff, compuesto por periodistas profesionales, escritores, intelectuales y humoristas gráficos, con alto grado de rotación. Entre ellos, para la actualidad política, César Seoane Cabral, Rodolfo Audi, Oscar Cardoso, Carlos Campolongo y Ricardo Contesti (bajo anonimato) entre otros. Osvaldo Granados y Claudio Bazán se encargaban del análisis económico; Luis Alberto Murray y Diana Ferraro escribían con regularidad en las secciones de Cultural y Juventud, mientras que Pascual Albanese lo hacía sobre temas internacionales y Osvaldo Pepe sobre deportes. El historiador Salvador Ferla y el periodista Mario Wainfeld eran colaboradores eventuales. El reconocido historietista Caloi publicaba cartoons de crítica social en la página final de la revista. Varios de los mencionados eran militantes justicialistas; Contesti, en particular, había sido diputado nacional hasta el golpe de Estado.

La Junta militar, impuesta en marzo de 1976, procuró una profunda reestructuración social por la vía autoritaria, mediante la apertura externa, la aplicación de un programa económico liberal-monetarista y el favorecimiento de la valorización financiera. Con ello apuntaba a clausurar el modelo de bienestar en crisis de los gobiernos justicialistas, emergentes de elecciones

${ }^{2}$ Como historiador, Rosa (1906-1991) integró la corriente revisionista, crítica de la interpretación denominada "liberal" de la historia argentina y que tendría -luego del golpe de Estado de 1955- gran predicamento y sería adoptada por el peronismo como parte de sus componentes doctrinarios. Se desempeñó como embajador en Paraguay y en Grecia de los gobiernos justicialistas entre 1973 y 1976. Véase Manson (2008), Devoto y Pagano (2009, pp. 254-260). 
democráticas en 1973 y 1974, que se habían centrado en el mercado interno, la recomposición de ingresos de los trabajadores y la concertación entre los actores económicos, políticos y sindicales. Desde la muerte del presidente Perón en ejercicio, en julio de 1974, el estancamiento económico, el conflicto social y el aumento de la violencia política habían acentuado la desarticulación de las fuerzas que habían acompañado la emergencia del nuevo régimen y la sensación de desgobierno. Las organizaciones revolucionarias, tanto las relacionadas con la izquierda peronista como las de tradición marxista, habían aportado a la caída de la dictadura precedente, pero permanecieron activas durante los gobiernos constitucionales de Cámpora y de Perón, como parte de la disputa por el poder dentro del peronismo y, en el caso del guevarista Ejército Revolucionario del Pueblo, mantuvieron el enfrentamiento con las fuerzas de seguridad. Ya con anterioridad a la muerte del líder justicialista, y en especial desde su sucesión por Isabel Martínez de Perón, la persistencia de la acción guerrillera alentó la implantación, desde la esfera estatal, de medidas legales y paralegales que preanunciaron la represión sistematizada posterior a 1976. Este panorama, sumado a la crisis económica, fue erosionando la legitimidad gubernamental y sentó, en definitiva, las bases para el golpe de Estado (Canelo, 2008; Franco, 2012; Novaro y Palermo, 2003). ${ }^{3}$

Para fines de la década, la dictadura había consumado la supresión de la mayor parte de la oposición política, armada y desarmada, y sindical, a través del terrorismo de Estado. No obstante, enfrentaba un descalabro económico y tampoco lograba consolidar un proyecto político que heredara e institucionalizara su orden de facto, dada las diferencias al interior de la alianza cívico-militar en el poder y las resistencias de los partidos tradicionales, a la espera de ver restaurada la actividad política suspendida desde 1976 (Canelo, 2008; Novaro y Palermo, 2003). El PJ se contó, para entonces, entre los partidos que comenzaron un proceso cauteloso de posicionamiento crítico respecto al régimen. Pasará de un tono moderado inicial a un paulatino recrudecimiento discursivo, fundado en el agravamiento de las condiciones socioeconómicas y las restricciones políticas y sindicales al inicio de la década los ochenta.

${ }^{3}$ Sobre los efectos sociales de la represión, véase Calveiro, 2004, y ConAdEP, 1985. Respecto a la identificación global de izquierdistas y peronistas bajo el rótulo "subversivo" durante la dictadura, véase Canelo, 2008, pp. 37-40. 
Línea se inserta en este último escenario. Si bien se trataba de un medio no orgánico partidario, mostraba afinidad ideológica con la ortodoxia peronista (Besoky, 2013) y el sector "verticalista", caracterizado por haberse manifestado en defensa de la presidente Isabel Perón luego de su derrocamiento y cautiverio, y por exigir su liberación y la reanudación de las actividades del Partido Justicialista bajo su liderazgo (véase Raíces y Borrelli, 2016). Su adversario interno, en tal sentido, era otro sector, el "antiverticalista", rebelde a la exmandataria y con intenciones de generar cambios en la estructura directiva partidaria. Esta escisión partidaria provenía de antes de 1976, en plena crisis gubernamental, y se había mantenido tras el golpe. Por otra parte, cabe añadir que ambas facciones compartían una concepción institucionalista republicana y habían coincidido en su rechazo al activismo revolucionario.

En la medida en que los principales partidos opositores comenzaban a articularse -incluido el justicialismo con los "verticalistas"- en torno a lo que, desde 1981 se conocerá como la Multipartidaria, Línea convocaría durante 1980-1982 a diversos dirigentes de otros partidos para que se pronunciaran en sus páginas en reclamo de la recuperación de las instituciones democráticas y de la convocatoria a elecciones. ${ }^{4}$ A su vez, esta ubicación en el mapa político la mantenía enfrentada a dirigentes "antiverticalistas" como Raúl Matera o Delia Parodi, dispuestos a negociar con el régimen de facto, en el marco del "diálogo político", un reinicio de la actividad partidaria en las condiciones tuteladas que pretendían imponer las autoridades castrenses. ${ }^{5}$

De acuerdo con lo anterior, las referencias políticas inspiradoras de Línea se centraban fundamentalmente en el último gobierno de Perón y su continuación con Isabel Martínez. Nutrían sus argumentaciones los preceptos del trunco "Proyecto Nacional" peroniano, la reivindicación de la doctrina de la "Tercera posición" autonómica de los bloques de la guerra fría (bajo la célebre consigna "ni yanquis ni marxistas"), y la fundamentación desde el

${ }^{4}$ Por ejemplo, en Línea, núm. 4, septiembre de 1980, pp. 36-40, Jorge Abelardo Ramos, del Frente de Izquierda Popular, el nacionalista Alberto Asseff, el Socialista Popular Simón Lázara y el líder renovador de la UCR, Raúl Alfonsín -futuro vencedor de las presidenciales de 1983-, se pronuncian sobre la inminente designación del general Viola como cabeza de la nueva Junta militar.

${ }^{5}$ Calificó a los "antiverticalistas" de oportunistas y "desertores". Véase "El papel de los dirigentes”, Línea, núm. 7, diciembre de 1980, pp. 39-41. Sobre el "diálogo político” oficial y las diferencias internas del justicialismo ante dicha instancia, véase el notable trabajo de González Bombal (1991, en especial pp. 52-57). 
acervo historiográfico revisionista. ${ }^{6}$ Para la revista, los gobiernos justicialistas de 1973-1976 habían sufrido una desestabilización que motivó la intervención militar posterior. Frente a la representatividad mayoritaria de aquellos, se habían alzado los "extremismos" como expresión coaligada de intereses minoritarios: "queda evidenciado que la oligarquía se manejará en un pinzado que, metodológicamente, usará por la izquierda al guerrillerismo desplegando las banderías de una Argentina imposible e indeseable, y por la derecha con la conspiración desplegando el Proyecto Político de una Argentina indeseable pero posible". ${ }^{7}$ Esta interpretación omitía toda referencia a la represión ilegal estatal desplegada desde 1974. Por su parte, las fuerzas armadas en el poder eran caracterizadas por su conversión facciosa en "partido militar" y su desobediencia a las autoridades constitucionales (Raíces, 2012, pp. 86-89).

\section{JUSTICIALISMO Y DERECHOS HUMANOS: APROXIMACIONES CAUTELOSAS}

Dentro de la progresión opositora del justicialismo, la cuestión de las violaciones a los derechos humanos aparentó por varios años ocupar un espacio secundario, pese a que el accionar represivo había alcanzado ostensiblemente a víctimas de identificación peronista. Hasta 1978 se producen algunas mesuradas declaraciones partidarias que advertían sobre la necesidad de limitarlo y reactivar de común acuerdo el juego político partidario. ${ }^{8} \mathrm{Al}$ mismo tiempo, se registraban participaciones a título individual de militantes justicialistas

${ }^{6}$ Sobre el "Proyecto Nacional" en la revista, véase J. D. Perón, "Fortalecer el ser nacional y desarrollar un profundo nacionalismo cultural", Línea, núm. 2, julio de 1980, pp. 31-34. Sobre la "tercera posición" en el marco de la política exterior de los gobiernos justicialistas, véanse Paradiso (2002, pp. 523-572), y Franco (2012, pp. 226-227).

7 C. Seoane Cabral, "Perón o la oligarquía", Línea, núm. 7, diciembre de 1980, pp. 24-28. Sobre el papel de las fuerzas armadas en la represión durante los gobiernos constitucionales previos a 1976 y la construcción de la figura del "subversivo", consúltese Franco (2012).

8 "Al gobierno de las Fuerzas Armadas y al pueblo argentino", declaración firmada por el PJ, el Movimiento de Integración y Desarrollo (MID) y otros partidos menores, 28 de agosto de 1978, citado en Yanuzzi (1996, p. 188). Según la autora, para estos partidos, "si había sido necesario recurrir a formas ilegales de represión -formas plenamente justificadas, según el texto, por lo extraordinario de la situación-, continuar haciéndolo por más tiempo significaría una pérdida mayor de consenso. Ahora se necesitaba la mediación de los grupos civiles, como legitimantes del 'Proceso'" (p. 188). 
en organismos de derechos humanos. ${ }^{9}$ Esta situación comienza a diversificarse con la visita de la Comisión Interamericana de Derechos Humanos (CIDH) en 1979, que recibe denuncias de familiares de desaparecidos y de los organismos. ${ }^{10}$ Algunos dirigentes del PJ, como Deolindo Bittel y Herminio Iglesias, y sindicales afines, como Lorenzo Miguel, rubrican una severa misiva dirigida a la CIDH, donde se señalaba la "desaparición de miles de ciudadanos" y se prevenía contra la posibilidad de que a "la lucha contra una minoría terrorista, de la que también hemos sido víctimas, se la quiera transformar en una excusa para implantar el terrorismo de estado". ${ }^{11}$ El documento difundido en la prensa revelaba el endurecimiento circunstancial de la postura de algunos sectores partidarios frente a las consecuencias represivas. En tal sentido, la cuestión de los desaparecidos venía a sumarse a la persecución de sindicalistas y a la proscripción política; ello revelaba la asunción de un discurso opositor más atrevido. Posteriormente, la visita que la CIDH realiza a Isabel Perón en su lugar de detención, permite que la dirigente exprese conceptos similares. ${ }^{12}$ Estas declaraciones hacían eco de las denuncias pero también apuntaban a establecer una diferencia entre la actuación represiva del gobierno justicialista y la de la dictadura, para remarcar la ilegitimidad y arbitrariedad de la última. Aunque no se asociaban a los reclamos de los organismos -de hecho, las denuncias previas a 1976 de algunos como la Asamblea Permanente de Derechos Humanos (APDH) no podía concitar sus simpatías-, anticiparon otros pronunciamientos similares. ${ }^{13}$

Linea atiende inicialmente la cuestión desde el tablero complejo de disputa geopolítica entre las potencias y sus esferas de influencia. En su nú-

9 Abogados de filiación partidaria como Alicia Oliveira intervenían en la presentación de habeas corpus por detenidos-desaparecidos, desde el Centro de Estudios Legales y Sociales (Vicente, 2006, pp. 60-61).

${ }_{10}$ Sobre la visita de la CIDH, véanse Gorini (2006, pp. 321-342); Novaro y Palermo (2003, pp. 278-318). Su eco entre los exiliados en Jensen (2012).

${ }^{11}$ Reproducida en Iribarne (2006, pp. 29-31), entrecomillados textuales. El término "terrorismo de Estado" comienza a difundirse en trabajos como el informe de denuncia de la Comisión Argentina de Derechos Humanos (CADHu) y publicado en Madrid en marzo de 1977, reedición argentina, CADHU (2014).

${ }^{12}$ Véase "Conceptos de la ex presidente sobre derechos humanos", Clarín, 12 de septiembre de 1979, pp. 2-3.

${ }^{13}$ Jensen (2012). Declaraciones posteriores al informe de las Primeras Jornadas Jurídico-Institucionales del PJ, "Democracia y Estado de Derecho", de agosto de 1981, y sucesivas declaraciones de la Multipartidaria. Véase, Iribarne (2006, pp. 131-150) y, para las declaraciones (desde mediados de 1981), La propuesta de la Multipartidaria (1982). 
mero 5, tras comentar la intención de varias naciones sudamericanas bajo dictaduras de suscribir un pacto de seguridad (como virtual versión pública del denominado "Plan Cóndor"), deduce que la política estadunidense de atención a la situación continental de derechos humanos supondría un medio de presión contra el expansionismo soviético y, coyunturalmente, sobre las dictaduras regionales, para intentar imponer sus intereses. ${ }^{14}$ Así, parecía que la dictadura era adoptada de modo ambivalente por los "imperialismos", que resguardaban sus intereses geopolíticos -incluida la URSS como socio comercial argentino, pese al anticomunismo declamado por el gobierno de facto- y no se guiaban por una genuina voluntad de resguardar los derechos humanos. ${ }^{15}$

Por otro lado, la revista también apelaba a opiniones eclesiásticas para legitimarse. En la entrevista del número 4 a monseñor Vicente Zazpe, obispo de la provincia de Santa Fe, ${ }^{16}$ este afirma que "a algunos sectores les molesta que la Iglesia reciba y escuche a los sectores obreros, a los familiares de los desaparecidos y de los detenidos sin proceso o con procesos eternizados, a los jubilados y a los pensionados. De alguna manera son ciudadanos sin voz o al menos sin suficiente voz." Haciéndose eco de un lema cristiano, pronto tomado como eslogan por la revista ("la voz de los que no tienen voz"), Zazpe alude a gestiones no compartidas por la totalidad de la institución. El prelado integraba el sector obispal que Ghío (2017) denomina "democrático moderado", caracterizado por adherir los principios del Concilio Vaticano II, y se pronunciaba contra los efectos de las políticas económicas y la restricción del derecho de agremiarse, a partir de la discusión de la Ley Sindical de facto de

14 “Santa alianza con el diablo", Línea, núm. 5, octubre de 1980, p. 10. Sobre el "Plan Cóndor", véase Armony (1999).

${ }^{15}$ Su balance de la gestión de Carter concluía: "derechos humanos sí, por cierto, pero -en lo que respecta a la Argentina- presiones para impedir un completo desarrollo nuclear, aplicación de la 'Enmienda Humphrey-Keneddy', misiones de 'buena voluntad' y toda una serie de sutiles maniobras que proyectaban la ominosa sombra de esa república imperial sobre una Argentina incapaz de generar un proyecto político, económicamente débil, con su soberanía puesta en tela de juicio". "La frustración del 'Carterismo'”, Línea, núm. 9, abril de 1981, pp. 20-21. La portada mostraba al nuevo presidente, Ronald Reagan, como un cowboy -el western había sido el género cinematográfico que lo popularizó en su carrera como actor- a caballo, con un garrote en una mano y la bandera estadunidense en la otra, bajo la leyenda "El regreso del garrote”. "La frustración del “Carterismo'”, Línea, núm. 9, abril de 1981.

${ }_{16}$ "Denunciar al Mal y anunciar la renovación”, Línea, núm. 4, septiembre de 1980, pp. 8-10. Otra autoridad católica reporteada es el padre Néstor Noriega, director de una revista catequística, que responde sobre los desaparecidos similarmente a Zazpe. "R. P. Noriega: contra el golpe”, Línea, núm. 28, septiembre de 1982, pp. 18. 
fines de $1979 .{ }^{17}$ Indirectamente, el reportaje reflejaba puntos de coincidencia entre parte de la jerarquía católica y sectores opositores. De ahí la adhesión de la revista a los principios socialcristianos originarios de la doctrina peronista. Resalta en las declaraciones de Zazpe, asimismo, la incorporación de la figura del detenido-desaparecido como víctima. Aunque su mención aislada la deja inmersa en la sumatoria de afectados por el crítico cuadro de situación social.

\section{LA CONCESIÓN DEL NOBEL Y EL REPORTAJE DE LÍNEA A PÉREZ ESQUIVEL}

Para 1980, la academia sueca otorga el premio Nobel de la Paz a Adolfo Pérez Esquivel, coordinador latinoamericano del SeRPAJ. Esta entidad había sido creada en 1974 desde una orientación doctrinaria cristiana para la defensa de los derechos humanos y la difusión de la no-violencia. Pérez Esquivel participará en la gestación de otros organismos como la APDH, el Movimiento Ecuménico por los Derechos Humanos (MEDH), Madres de Plaza de Mayo, entre otros, durante la dictadura. En abril de 1977 es arrestado y permanece detenido catorce meses a disposición del poder ejecutivo, siendo liberado por presiones internacionales. Su distinción atrae un gran interés internacional por la situación de derechos humanos en Argentina y debilita el discurso oficial sobre la existencia de una "campaña antiargentina" orientada por los exiliados. En el plano doméstico genera la apertura al tema con el apoyo de distintos referentes políticos, sociales, sindicales, eclesiásticos y culturales, muchos de los cuales habían evitado pronunciarse, hasta ahora que comenzaban a apoyar los reclamos de los organismos (Canelo, 2008, pp. 149-150; Gorini, 2006, pp. 395-399). Por otra parte, la prensa recibió presiones del gobierno para reducir la cobertura del acontecimiento, si bien su difusión en algunas portadas y las críticas continuadas a la situación económica demostraban para entonces su progresivo distanciamiento del régimen (Blaustein y Zulueta, 1998, p. 250).

Significativamente, la edición contemporánea de Línea con el reportaje ostenta como tema de portada la ópera rock Evita, de Andrew Lloyd-Weber, lan-

${ }_{17}$ Zazpe era conceptuado por el SERPAj como un progresista afín a las directrices del "Documento de Puebla" del Consejo Episcopal Latinoamericano, aprobado en 1979 en su III Conferencia (en la que había participado). Gorini (2006, p. 383). Sobre las diferencias internas en la Iglesia en cuanto al acompañamiento de la dictadura y la cuestión de los desaparecidos, véase Ghío (2007). 
zada en 1978 y a punto de estrenarse en España. ${ }^{18}$ La revista comenta la versión inglesa original para efectuar una reivindicación de la significación sociopolítica de la dirigente, sugerida en el titular de portada: “¿ópera o historia?” Le permite, igualmente, colocar en los kioscos su efigie en la portada, contrariando la autocensura imperante en la prensa sobre la iconografía peronista (véase imagen 1).

Ahora bien, ipor qué Línea entrevista al coordinador del SERPAJ, dada su escaso y cauteloso tratamiento de las cuestiones de derechos humanos? El discurso defensor de la institucionalidad democrática de Pérez Esquivel marca una afinidad preliminar con la revista. Asimismo, la adscripción católica del SERPAj marca otro terreno común; de hecho, el obispo Zazpe había hecho pública su adhesión al galardonado (Homenaje, 1980, p. 7). Por último, considerada la repercusión del acontecimiento, la revista podía aspirar, mediante su figura, a atraer adicionales lectores críticos del panorama imperante.

El editorial reseña de modo irónico una declaración oficial sobre la premiación, caracterizada por la sorpresa ante el reconocimiento a un exponente de organismos que eran acusados de defender "subversivos". ${ }^{19}$ Línea, por su parte, destaca la relevancia internacional de Pérez Esquivel y concede que "hoy se sabe en todas partes -y se comenta- que el premiado fue torturado y estuvo preso por el delito de cumplir 'humanitaria' tarea”. ${ }^{20}$ El editorial culmina desacreditando las imputaciones respecto a que el discurso pacifista del galardonado habría favorecido al terrorismo y justificaría sus padecimientos personales. ${ }^{21}$ Cuando la declaración oficial lo liga con el inicio del "accionar subversivo" en 1969 -año del Cordobazo-, Línea atribuye el inicio de la "subversión" al golpe de Estado de 1955 contra el segundo gobierno justicialista. ${ }^{22}$ Este desvío de la "subversión" izquierdista al golpismo cívico-militar le permite asemejar a este último con el terrorismo y comparar la denominada "Revolución Libertadora” con las intenciones fundacionales de la dictadura en curso. Y ubicar al peronismo como una fuerza política democrática, víctima

${ }^{18}$ El estreno se produjo el 23 de diciembre de 1980 en el Teatro Monumental de Madrid.

19 "Comunicado de la Secretaría de Información Pública", La Nación, 15 de octubre de 1981, pp. 2 y 19.

${ }_{20}$ Rosa, J. M., "El gobierno y el premio Nobel”, Línea, núm. 6, noviembre de 1980, p. 1.

${ }^{21}$ Rosa, J. M., "El gobierno y el premio Nobel”, Línea, núm. 6, noviembre de 1980, p. 1.

${ }^{22}$ El 16 de septiembre de 1955 se inició el golpe de Estado, denominado "Revolución Libertadora”, que derrocó al régimen constitucional de Juan Domingo Perón. El movimiento conocido como Cordobazo se desencadenó en las calles de la ciudad de Córdoba a partir del 29 de mayo de 1969, encabezado por obreros, empleados y estudiantes, y marcó el final del gobierno dictatorial del general Juan Carlos Onganía. 


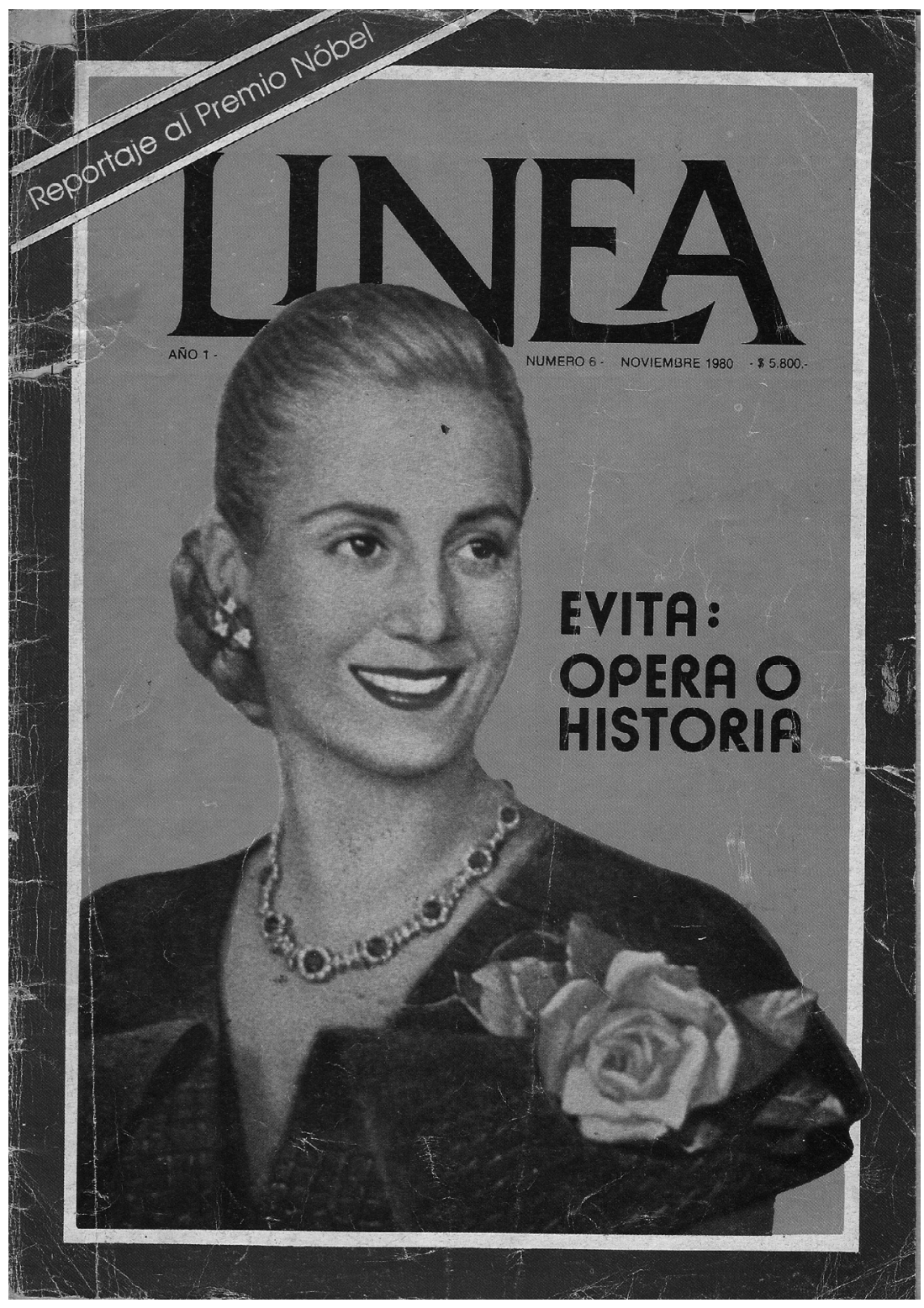

Imagen 1. Portada. Línea, núm. 6, noviembre de 1980. 
injusta de las interrupciones institucionales. La conclusión del editorial resultaba lapidaria:

Aceptemos que los comunicados del gobierno tengan por infradotados a los argentinos. Son cosas de entre casa que entendemos y disculpamos. Pero que un documento relacionado con el Premio Nobel quiera explicar a una audiencia que debe suponerse amplia, ágil y (¿acaso no lo sabe?) mal dispuesta hacia los gobiernos militares, la necesidad de castigar a pacifistas y abogados en defensa de "los valores caros a Occidente", y del Estado de Derecho pasa del límite que Maquiavelo puso entre crimen y tontería. ${ }^{23}$

Línea encontraba en la destemplada reacción oficial una muestra de su descrédito discursivo generalizado y señalaba la existencia de un amplio conglomerado de descontentos al que su discurso no interpelaba (y a los que la revista pretendía atraer). Así, el caso de Pérez Esquivel le permitía, en esta oportunidad, desacreditar al régimen. Mas las violaciones a los derechos humanos como fundamentación del Nobel concedido no aparecían tematizadas, como muestra de su relativa importancia en el contexto del discurso político de la revista. ${ }^{24}$

\section{El reportaje}

La entrevista, titulada “¿Pacificación o revancha?”, ${ }^{25}$ anticipaba desde el título definido por la revista la contradicción entre un valor socialmente ponderable -la pacificación-y otro condenable -la revancha-, que la revista deseaba posar sobre la figura del premiado. A su defensa de Pérez Esquivel en el editorial frente a la dictadura, adicionaba la que, situándolo al interior del campo opositor compartido, lo tomaría con suspicacia. pp. 10-13.

${ }^{23}$ José María Rosa, “El gobierno y el premio Nobel”, Línea, núm. 6, noviembre de 1980,

${ }^{24}$ Pese a que el director de Línea había firmado, a pocos meses de su lanzamiento, una solicitud de reclamo por las listas de desaparecidos, junto a otras personalidades intelectuales, eclesiásticas y políticas. Clarín, 12 de agosto de 1980. Ella "marcó el comienzo de un pasaje de numerosos intelectuales y dirigentes políticos y sociales hacia la participación activa en la lucha de derechos humanos" (Gorini, 2006, p. 396). Su adhesión a título personal tampoco eximió a Línea, según se advierte, de diferenciarse de las reclamaciones de los organismos.

25 “Pérez Esquivel. ¿Pacificación o revancha?", Línea, núm. 6, noviembre de 1980, pp. 10-13. 
Es revelador, en el mismo sentido, el copete introductorio, ya que su mediación indica cómo debieran a tenor de la revista comprenderse las declaraciones de Pérez Esquivel. ${ }^{26}$ Su primer párrafo atribuye a los "sectores medios" la expectativa preferente por el premiado y califica sus reacciones de "revancha", estipulando de este modo la raigambre social presunta del movimiento de derechos humanos. ${ }^{27}$ Así, es introducido como representante de sectores diferenciados de la base popular y plebeya peronista que la revista reivindica para un asunto, por añadidura, poco familiar al repertorio reivindicativo de tal tradición política. Los derechos humanos eran tomados, desde esta perspectiva, como representativos de quienes la revista reconocía como parte sustancial de sus lectores. ${ }^{28}$ En paralelo, Línea destaca la prudencia en la declaraciones demostrada por la mayoría de los partidos políticos frente al acontecimiento, hecho que le permite establecer sus propias precauciones sobre una figura que habría sido objeto de manipulación. Por cuanto

la "polarización" entre las voces reaccionarias que repudiaron [el premio a Pérez Esquivel] y los aplausos de los agentes internacionales (Timmerman [sic], Firmenich, etc.) intenta[n] dejar escaso margen para una posición verdaderamente nacional.

[...] No nos seducen los aparentes enfrentamientos entre la izquierda y la derecha [...]. Observamos como falsa polarización en la que se pretende embretar a nuestro Pueblo: o con las organizaciones internacionales (disfrazadas de humanistas para ocultar sus objetivos neocolonialistas) o con este gobierno cuya cabeza real es parte de ese poder mundial capitalista que lleva cinco años de destrucción nacional. ${ }^{29}$

${ }^{26}$ Véase Leñero y Marín (1986, p. 45).

27 “Pérez Esquivel. ¿Pacificación o revancha?", Línea, núm. 6, noviembre de 1980, pp. 1013, entrecomillados textuales. Tanto las organizaciones preexistentes al golpe de 1976 como en las posteriores como Madres de la Plaza de Mayo, Abuelas y Familiares, se ubican en conjunto en torno a las clases medias urbanas, sean los estratos superiores del empleo fabril, de servicios o en las profesiones liberales. Ello surge también del relevamiento de la ocupación de los desaparecidos registrados, véase CONADEP (1985).

${ }^{28}$ Una nota sobre la exitosa novela de Jorge Asís, Flores robadas en los jardines de Quilmes, señala que "El tema que desarrolla 'prendió' mucho en la generación intermedia intelectual argentina, que en buena parte son nuestros lectores; de ahí la casi obligación de emitir una opinión de este libro". "Flores robadas de [sic] los jardines de Quilmes", Línea, núm. 8, marzo de 1981, pp. 44-45. Esta "casi obligación" subraya la autoconciencia de Línea sobre su público lector.

29 “Pérez Esquivel. ¿Pacificación o revancha?”, Línea, núm. 6, noviembre de 1980, pp. 10-13. 
El trasfondo del Nobel, como vuelve a ponerse de manifiesto, encubriría la pugna entre los bandos foráneos y sus personeros y la "posición nacional”. El bando detractor de Pérez Esquivel respondería al autoritarismo gobernante y sus políticas neoliberales. Y el favorable, a los "agentes internacionales" Timerman y Firmenich, sindicados de izquierdistas, y a organizaciones con finalidades igualmente "neocoloniales" ${ }^{30}$ Otro texto posterior condena la participación, a principios de 1981, en el Coloquio sobre la Política de Desaparición Forzada de Personas de París, de los dirigentes justicialistas Vicente Saadi y Esteban Righi y del sindicalista combativo Raimundo Ongaro-los dos últimos exiliados- $-{ }^{31}$ junto a Pérez Esquivel, Timerman e Hipólito Solari Irigoyen -ex senador de la UCR, secuestrado durante la dictadura y exiliado-. Reprocha la falta de invitación formal al PJ, que contaría con una "clara posición fundada en sólidos principios doctrinarios" en la materia, y descalifica a los asistentes como una "conjunción de 'agentes" bautizada como "nueva Unión Democrática" ${ }^{32}$ En suma, tanto la presentación de la entrevista como notas posteriores, mientras mostraban una defensa política del premiado ante la dictadura, paralelamente recelaban posibles motivaciones ocultas del movimiento de derechos humanos y de sus vinculaciones.

Estas premisas conflictivas tiñen las preguntas inaugurales de la entrevista. Las dos primeras le requieren a Pérez Esquivel posicionarse entre la "derecha" y la "izquierda" ideológicas, además de inquirirlo sobre una posible

${ }^{30}$ Sindicados de izquierdistas y organizaciones con finalidades igualmente "neocoloniales". Timerman, exdirector del diario La Opinión, había apoyado el golpe de Estado, pero posteriormente sería secuestrado y torturado en 1977. Liberado en 1980 por presión internacional, desde su exilio en Estados Unidos promovió la denuncia de las violaciones a los derechos humanos. Véase Blaustein y Zulueta (1998). Por su parte, Mario Firmenich, líder de la organización armada Montoneros, se había exiliado en 1976 en Italia.

${ }^{31}$ Saadi, exgobernador de la provincia de Catamarca, se había ido acercando, tras el golpe de Estado, a posiciones críticas de la dictadura. Righi fue ministro del Interior del breve gobierno de Héctor Cámpora (1973). Ongaro, dirigente del gremio gráfico, se había exiliado tras permanecer detenido y ser asesinado uno de sus hijos por la Alianza Anticomunista Argentina (AAA), en 1975.

32 "Derechos humanos. Una noble causa mal representada", Línea, núm. 8, abril de 1981, p. 26. Entrecomillados textuales. La Unión Democrática fue conformada por los partidos Unión Cívica Radical, Socialista, Demócrata Progresista y Comunista para las elecciones presidenciales de 1946 y enfrentó a la fórmula del Partido Laborista, la UCR-Junta Renovadora y Partido Independiente, encabezada por el coronel Perón, vencedor en los comicios (luego los tres partidos serían unificados en el Partido Único de la Revolución Nacional y, poco tiempo después, el PJ). Otros destacados ponentes argentinos del Coloquio fueron Emilio Mignone, presidente del CELS, el escritor Julio Cortázar y el expresidente Arturo Illia. Novaro y Palermo (2003, p. 494). 
parcialidad del SERPAj en la atención a las víctimas. Su respuesta abre la estrategia argumentativa que emplazará en lo sucesivo: justificar la defensa de los derechos humanos apelando a valores universales de justicia, respeto al disenso y convivencia democráticas con base en la doctrina cristiana, y recusar la adscripción de tales principios a polos ideológicos. Con esa base, declara su compromiso con los sectores sociales postergados y connota los derechos humanos como finalidad social y no (directamente) política, evitando ubicarse en los extremos marcados por Línea.

La revista insiste por la misma vía sucesivamente, reafirmando el tono tribunalicio (Arfuch, 1995) del diálogo, y obtiene una contestación acorde: "Nosotros lo que llevamos es el mensaje del Evangelio a todos los hombres. Pero tenemos opción y un compromiso con los más pobres [...]. Nosotros durante mucho tiempo hemos condenado el terrorismo por lo inhumano, por lo antievangélico y porque atenta contra Dios y contra la humanidad." La alusión a la "opción preferencial por los pobres", posición teológica surgida de los Concilios de Medellín y de Puebla de 1968 y 1979, reafirma el carácter ecuménico de su labor y desmiente cualquier intención apologética de la insurgencia.

Si la intención de Linea apuntaba a obtener el repudio de Pérez Esquivel del accionar guerrillero, las siguientes interrogantes indagan lo que para la revista sería su opuesto discursivo (y moral): la legalidad republicana democrática. Al consultarlo sobre la relación entre la defensa de los derechos humanos y la de los derechos políticos, concede que la soberanía popular expresada en las urnas es la base de la defensa de los derechos fundamentales y atribuye la "violencia institucionalizada" estatal a la injusticia económica y la miseria. Al fundamentarse en la cita de autoridad del obispo brasilero Hélder Cámara, un exponente fundamental de la Teología de la Liberación, puede en tal sentido relacionar la situación argentina con la de otros gobiernos dictatoriales latinoamericanos. Por similar camino discurre Pérez Esquivel al instarlo a que dirima entre "la ley y el llamado terrorismo de Estado" para la resolución del "embate subversivo" bajo un gobierno constitucional. ${ }^{35}$ Esta disyuntiva tomaba partido implícito, por lo que para Línea habría sido la legítima represión gubernamental justicialista, en contraste con la indiscriminada e ilegal de la dictadura posterior. Para esta, reservaba el concepto "Terrorismo de Estado", familiar al movimiento de derechos humanos y cuyas primeras

\footnotetext{
33 “Pérez Esquivel. ¿Pacificación o revancha?”, Línea, núm. 6, noviembre de 1980, pp. 1013. Entrecomillados textuales.
} 
menciones discursivas justicialistas se remontaban -como se ha visto- a la carta a la CIDH. Esta legitimación se observa en su pregunta posterior, donde le propone explicar las razones por las que la guerrilla "atacó al Gobierno del Gral. Perón, elegido democráticamente y portador de un proyecto legítimo, de sociedad justa y pluralista, de amplia participación popular”. Estos planteamientos permitían que Línea se reivindicara desde un espacio democrático de exclusión de los represores y de los insurgentes guerrilleros; al asemejarlos, anticipaba la imagen de los extremismos enfrentados al margen del Estado de derecho y la sociedad, o "teoría de dos demonios". ${ }^{34}$

En su contestación, el galardonado calificaba a la guerrilla de "inhumana" y situaba su inicio en los gobiernos militares de los primeros 70 años, con lo que retomaba su razonamiento sobre los Estados de opresión social que la ocasionaban y quitaba el foco de las organizaciones revolucionarias en la desestabilización institucional. Acto seguido, al preguntársele sobre "cierta insolidaridad internacional" hacia el peronismo en las persecuciones y cautiverio de su líder Isabel Perón, que buscaba mostrarlas como una violación de derechos humanos, evita pronunciarse sobre el caso particular y muestra su denodada resistencia a que se redujera la labor de los organismos en parámetros político-partidarios. Reconoce, en cambio, sus contactos con los sindicatos peronistas del Grupo de los $25,{ }^{35}$ pero con cierta distancia, al admitir vínculos con otros sectores gremiales.

Por el contrario, la observación de que algunos analistas políticos le habían atribuido la intención de "tenderle una mano al gobierno", a propósito de un comunicado del SERPAJ donde demandaba información oficial sobre los desaparecidos y apelaba a la "reconciliación y la fraternidad", a partir de un mensaje papal, demostraba que Línea parecía decidida a intentar encuadrarlo de un modo u otro. A ello, responde que: "Nosotros estamos con las manos

34 Tal interpretación, existente antes del golpe de Estado -en especial, en los ámbitos oficiales-, era compartida por gran parte del espectro político de la época, y tuvo síntesis argumentativa en el informe de la Comisión Nacional sobre la Desaparición de Personas, publicado en 1984, con el prólogo del escritor Ernesto Sabato, denominado Nunca más. Sería puesta en cuestión especialmente por el movimiento de derechos humanos, procurando que se contemplara a las víctimas de la represión como tales antes que como "subversivos" por su militancia, frente al tratamiento judicial. Véase Franco $(2015,2018)$.

35 Se lo consulta sobre su postura respecto a la restauración de los derechos gremiales que este gobierno habría “inculcado" [sic]. "Pérez Esquivel. ¿Pacificación o revancha?”, Línea, núm. 6, noviembre de 1980 , pp. 10-13. El término correcto sería "conculcado", dado que "inculcar" supone la acción formativa. 
abiertas para dialogar con todos los sectores políticos, culturales, religiosos y tenemos que encontrar de qué manera podemos ir aportando elementos que permitan aportar a un reencuentro de los argentinos, pero pienso que para que eso sea posible debe restablecerse la justicia en la verdad." ${ }^{36}$ Su cautelosa respuesta recuperaba el mencionado término "reconciliación", presente ya en su discurso de aceptación del Nobel, ${ }^{37}$ y relacionado con las tentativas eclesiásticas de promover el acercamiento entre la oposición y el gobierno de facto a partir de su posición ambivalente frente a este último -entre el apoyo y algunos conatos críticos, como los de Zazpe-. Y también ante las iniciativas oficiales de atraer a las dirigencias partidarias a través de la convocatoria a rondas de "diálogo político". ${ }^{38} \mathrm{La}$ "reconciliación nacional" será, finalmente, el lema adoptado por el Episcopado en el influyente documento "Iglesia y comunidad nacional", donde se la relaciona, como lo hace Pérez Esquivel, con la "verdad" y la "justicia". El término igualmente integrará las declaraciones de la Multipartidaria como signo de su moderantismo y de su intención de concitar el respaldo eclesiástico. ${ }^{39}$

No obstante, la relación establecida por el Nobel entre la "reconciliación" y los reclamos de "verdad y justicia" en torno a las desapariciones forzadas y la determinación de las responsabilidades estatales respectivas, colisionaba la negación oficial. El "diálogo" que sugería el Nobel en delibera-

36 “Pérez Esquivel. ¿Pacificación o revancha?", Línea, núm. 6, noviembre de 1980, pp. 1013. En su misiva al III Congreso Mariano Nacional, fechada el 11 de octubre de 1980, el papa había exhortado a los fieles locales: "amad a vuestros hermanos, particularmente a los que en la actualidad sufren y lloran, de modo que la sociedad argentina, consolidada sobre los pilares del amor fraterno y de la reconciliación, pueda exclamar de verdad: 'Ved cuán bueno y deleitoso es convivir juntos los hermanos"”. Recuperado de https://w2.vatican.va/content/john-paul-ii/es/ messages/pont_messages/1980/documents/hf_jp-

37 En su discurso expresa: "Y para construir esa nueva sociedad debemos estar con las manos abiertas, fraternas, sin odios, sin rencores, para alcanzar la reconciliación y la Paz, pero con mucha firmeza, sin claudicaciones en defensa de la Verdad y la Justicia." Recuperado de http://www.adolfoperezesquivel.org/

${ }^{38}$ Sobre el “diálogo político”, véase González Bombal (1991); su valoración por Línea en Raíces y Borrelli (2016).

${ }_{39}$ El documento fue emitido en mayo de 1981. Véase Conferencia Episcopal Argentina, "Iglesia y Comunidad nacional". Recuperado de http://www.cea.org.ar/07-prensa/iglesia_y_ comunidad_nacional_1.htm En ella, se justifica la lucha "antisubversiva", aunque se cuestionan los métodos empleados a tal fin. Un análisis de Línea de la declaración en Martín Raúl Alberca, "Iglesia y Comunidad", en Línea, núm. 13, agosto de 1981. Para la recuperación político-partidaria del término, véase La propuesta de la Multipartidaria (1982). 
da reminiscencia con el cívico-militar, tendía en consecuencia a excluir a las autoridades, al no creer en su voluntad sincera de encarar estas cuestiones. ${ }^{40}$

Luego de recordar su extenso cautiverio, un gráfico silencio de su parte, traducido en el texto en puntos suspensivos, sigue a la última pregunta de Línea sobre su opción electoral en caso de producirse elecciones. Señal última de la desconfianza mutua que había guiado la entrevista y había supuesto recomendar a los lectores una interpretación entrelíneas de cada dicho y silencio de Pérez Esquivel. ${ }^{41}$ Por otra parte, al centrarse en las implicancias políticas del galardón, tanto el editorial como la entrevista dejaban en un ostensible segundo plano las referencias a los mecanismos represivos del Estado, a sus víctimas y a la campaña de denuncias de los organismos, motivo central de la premiación.

\section{LOS DESAPARECIDOS, UNA REFERENCIA OBLICUA}

De acuerdo con lo anterior, en los primeros números, Línea no problematiza directamente la cuestión de las desapariciones forzadas de personas. Sin embargo, su instalación en la agenda mediática mantiene eco en ella, al integrar a los afectados por las políticas del régimen, como se desprendía de las declaraciones de monseñor Zazpe. Replican esta consideración dos menciones en las contraportadas, aplicadas a la sátira política similarmente a la de otras revistas como Humor. La primera apuntaba a cuestionar el realizado Censo Nacional de Población y Vivienda de 1980 y su publicidad (véase imagen 2). ${ }^{42}$

Una parodia del sello recibido como comprobante por los encuestados encabeza la composición, reemplazando la leyenda original "Yo respondî" por un "Los que no pudieron responder". A esa viñeta le seguía una lista que mencionaba a los, para la revista, numerosos ausentes de la consulta y víctimas de sus políticas, entre ellos los desaparecidos. Casi un año después volvería a emplear el recurso, al mostrar la representación de un ficticio juego de mesa, inspirado en la declaración de una autoridad militar que descartaba la

40 “Pérez Esquivel. ¿Pacificación o revancha?”, Línea, núm. 6, noviembre de 1980, pp. 10-13.

${ }^{41}$ “Pérez Esquivel. ¿Pacificación o revancha?”, Línea, núm. 6, noviembre de 1980, pp. 10-13.

${ }^{42}$ Véase Línea, núm. 6, noviembre de 1980, contraportada. La apelación al humor y diseño gráficos para tematizar la actualidad política en las portadas y, sobre todo, en las contraportadas, se debe al grupo Equipos de Difusión, compuesto por publicistas y vinculado al PJ. Véase Borrelli y Raíces (2018). 


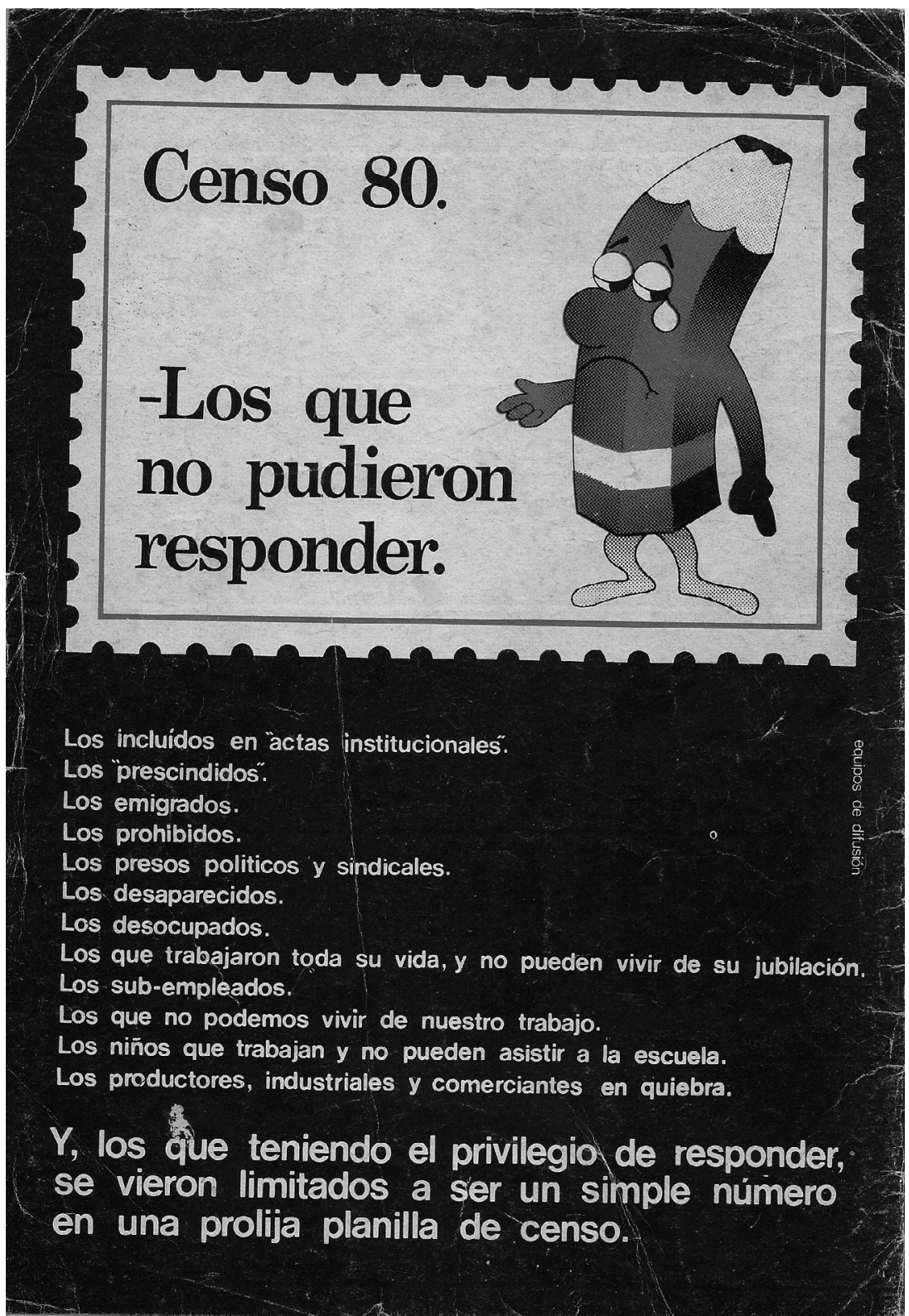

Imagen 2. Contraportada. Línea, núm. 6, noviembre de 1980. 
convocatoria a elecciones en el breve plazo. ${ }^{43}$ El entretenimiento contemplaba opciones (y constricciones) para los principales partidos participantes del "juego" político, personificados en fichas de jugador. Uno de los casilleros de penalidad en el trayecto planteado establecía: "Casillero de los desaparecidos. Debe desaparecer inmediatamente del juego." ${ }^{44}$ Esta alternativa figuraba a un sujeto político presente por ausencia y recordaba que los militantes seguían bajo amenaza de la represión estatal. Pero, una vez más, esta forma de figurar la desaparición redundaba entre otras penalidades de un juego en cuya entidad metafórica se advertía el discreto nivel de relevancia concedida al tema y el énfasis dado a "reclamar la urna" como recuperación del sistema político republicano democrático (véase imagen 3 ).

Será un colaborador, el historiador revisionista Salvador Ferla, quien avance con un pronunciamiento más explícito. Un artículo suyo señalaba que los perjuicios de las políticas económicas promoverían futuros desbordes "subversivos" y proponía al justicialismo como fuerza resolutoria de la "tragedia argentina" del enfrentamiento entre extremismos. Haciendo referencia indirecta al documento "Iglesia y comunidad nacional", postula que:

La Iglesia exhortó al gobierno que en el marco de la indispensable reconciliación le dé alguna satisfacción a los familiares de los desaparecidos. Creemos que hace falta más aún; hace falta demostrar que las desapariciones obedecieron pura y simplemente al propósito de apagar las llamas de violencia y no al de restaurar un régimen de oprobios. La jerarquía militar le debe una satisfacción a la memoria de sus soldados muertos, a quienes monseñor Bonamín prometió el Cielo por su lucha contra los extremistas ateos, pero no a cambio del Infierno para sus deudos. Sería un agravio que el sacrificio de la juventud fuera exclusivamente en beneficio de la una oligarquía imbécil que pretende suicidarse junto con el país, y de la tilinguería soberbia, feliz porque el "proceso" le permitió viajar a Miami y especular con los dólares. ${ }^{45}$

43 "Las urnas están bien guardadas, y van a seguir bien guardadas", fue la declaración en marzo de 1980 del flamante comandante en jefe del ejército, general Leopoldo Fortunato Galtieri. Véase Canelo (2008, p. 160).

${ }^{44}$ Línea, núm. 13, agosto de 1981, contraportada. Un análisis previo en Borrelli y Raíces (2018).

${ }_{45}$ S. Ferla, "La falacia básica del Proceso", Línea, núm. 13, abril de 1981, pp. 16-17. Todos los entrecomillados previos son textuales. Victorio Bonamín fue provicario castrense entre 1975 y 1983. 


\section{LA BUSQUEDA DE LA URNA \\ "Las urnas están bien guardadas"}

Esta frase célebre del filósofo contemporáneo Leopoldo Fortunato fué la que nos inspiró para crear este divertidísimo juego cívico-didáctico. El mismo fue ideado con el propósito de que todos los ciudadanos que participen se capaciten jugando y aprovechen así, el valioso tiempo que perderían en el innecesario acto de elegir a sus autoridades.
INSTRUCCIONES

Este simple juego no tiene límites en cuanto al número de ciudadanos que quieran participar. Consiste en arrojar un dado e ir avanzando con su ficha por los casilleros, siguiendo las indicaciones políticas que contienen los mísmos.

Pegar sobre cartulina y recortar

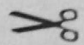

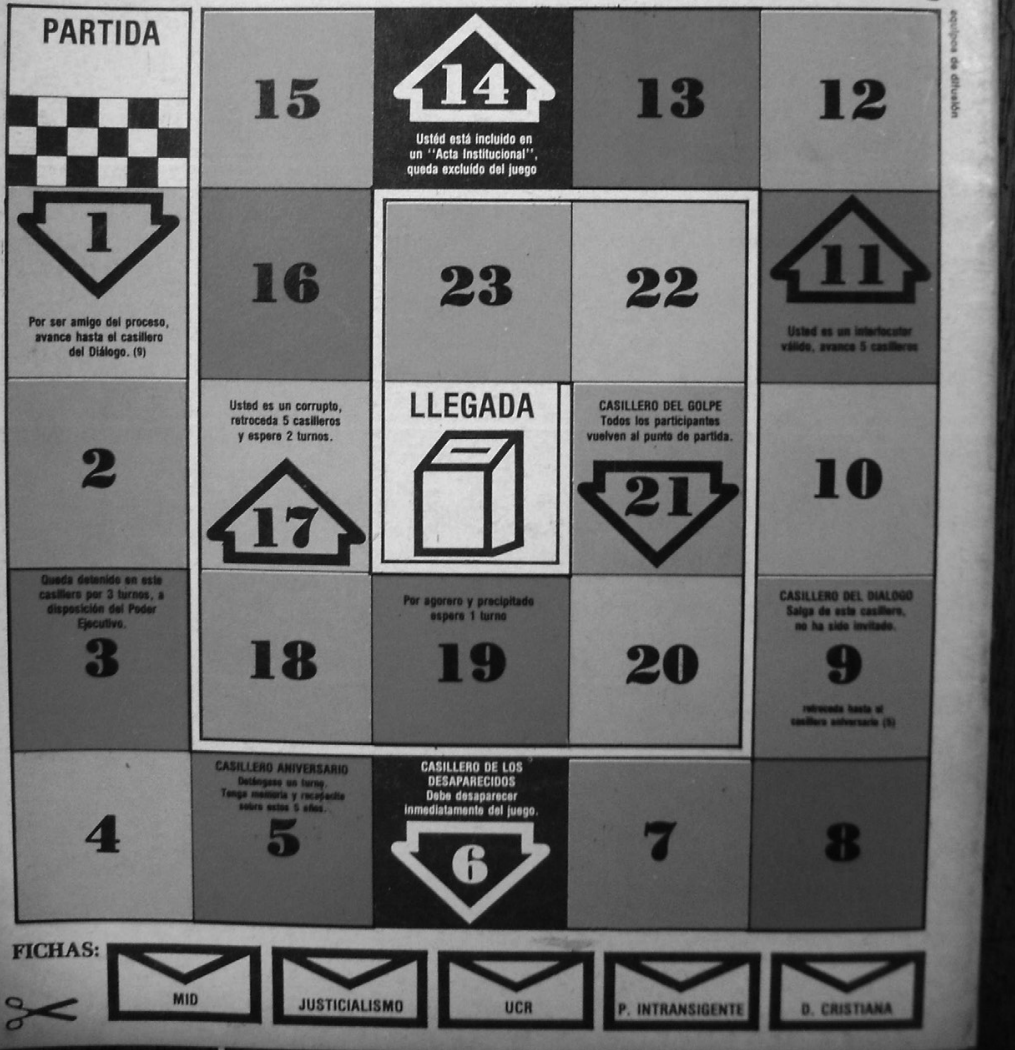

Imagen 3. Contraportada. Línea, núm. 13, agosto de 1981. 
Esta construcción discursiva abre una vía para convalidar la represión estatal ilegal sobre la base de su eventual utilidad para la paz social. Los soldados caídos en tales faenas son homologados con los desaparecidos por una común pertenencia generacional juvenil y su condición equivalente de víctimas sacrificiales de los intereses del régimen. Serían beneficiarios del holocausto de unos y otros la "oligarquía" y los "tilingos", figuraciones jauretcheanas de la clase dominante y de las clases medias que les son funcionales. ${ }^{46}$ De tal modo que este cuadro nuevamente reducía la suerte de los desaparecidos a una cuestión de seguridad interna manipulada por el régimen, pero sin problematizarse ni cuestionarse la metodología ilícita empleada.

\section{"INOCENTES" Y “CULPABLES": LA CUESTIÓN DE LOS NIÑOS DESAPARECIDOS Y APROPIADOS}

Con la caída de la Junta, presidida por el general Viola a fines de 1981, y su reemplazo de la facción castrense "dura", encabezada por Galtieri, que abandonó la actitud de negociación con las fuerzas políticas (Canelo, 2008, pp. 177-178), se abre un nuevo lapso de aumento de las manifestaciones disidentes y opositoras. Para entonces, la organización Abuelas de Plaza de Mayo, existente desde 1977, convoca a la creación de una nueva entidad, el Movimiento por la Recuperación de los Niños Desaparecidos, como espacio transversal de visibilización de la problemática del secuestro, desaparición y apropiación de niños. Es presidida por Ernesto Sabato e integrada por el obispo católico Jaime de Nevares, el teólogo José Míguez Bonino, el obispo anglicano Ricardo Cutts, el rabino Marshall Meyer -activo en el Movimiento Judío por los Derechos Humanos-, el presidente de la Academia Argentina de Letras, Bernardo Canal Feijoó, la cantautora y poeta María Elena Walsh y Pérez Esquivel. Línea anuncia en portada las declaraciones de prensa respectivas de Sabato y

${ }^{46}$ Sobre las categorías "oligarquía" y "tilingo", véase Jauretche (1973); respecto a Arturo Jauretche como intelectual, véase Neiburg (1998, pp. 53-63); otro artículo previo de Línea señala que la "consciencia nacional" que el peronismo promueve, combate la alienación juvenil que la lleva al "extremismo". "La despolitización por la idiotización”, Línea, núm. 1, junio de 1981, pp. 43-44. De acuerdo con las estadísticas publicadas en Nunca Más, en efecto la mayoría de los desaparecidos eran de condición juvenil. Véase CoNADEP (1985). 
Pérez Esquivel, titulándolas "Los niños siempre son inocentes". ${ }^{47}$ Al respecto, las alegaciones sobre la inocencia de los desaparecidos, como estrategia para legitimar las demandas de aparición con vida, integraban el discurso de familiares y organismos y se extendían a los niños apropiados. Crenzel (2010, p. 70) señala que, en un escenario signado por el terror, enarbolar la condición de "víctimas inocentes" de los desaparecidos procuraba convalidar el reclamo ante las autoridades y los organismos humanitarios receptores de denuncias y evitar el aislamiento del propio círculo de parientes y allegados.

Pero el empleo del término "siempre" en el titular introducía una sombra de duda contrastante sobre los desaparecidos adultos. Por cuanto tiene el efecto semántico de sugerir que -no muy lejos de lo que insinuaba Ferla-, algunos o todos ellos resultarían "culpables" y podrían merecer el destino sufrido a manos de las fuerzas de seguridad. La revista sugiere, así, un deslinde entre afectados donde el interés reivindicativo aparece puesto en los menores. Esta actitud se apoya en las afirmaciones de Sabato, que extreman la estrategia de organismos y familiares de proclamar a los niños "inocentes absolutos" en tanto, según el novelista, "los grandes somos siempre culpables del algo". Las afirmaciones de Pérez Esquivel contrastan con la anterior al expresar la convicción de que la gran mayoría de los niños apropiados se encontraban con vida y desestimar las acusaciones oficiales de corrupción y subversión atribuidas a los desaparecidos adultos. ${ }^{48}$ Su mirada totalizadora elude abordar la cuestión de cualquier culpabilidad presunta de las víctimas y denuncia la responsabilidad criminal e informativa estatal. Por su parte, la revista anticipa estas declaraciones, como hiciera con la entrevista al Nobel, mediante una suerte de "advertencia preliminar" que reitera su intención de separar su interés por los derechos humanos de cualquier conexión con una insurgencia revolucionaria que condena: "Es conocida la posición de Línea respecto del terrorismo sustentada en los mejores principios del pensamiento nacional y en la consideración de que el terrorismo constituyó el instrumento de provo-

47 “Los niños siempre son inocentes”, Línea, núm. 18, enero de 1982, pp. 10-11. Información del Movimiento, "Un movimiento por los niños desaparecidos", La Prensa, 12 de diciembre de 1981, p. 7; CELS (1982, p. 6); Crenzel (2010, p. 78).

48 Ambas en "Los niños siempre son inocentes", Línea, núm. 18, enero de 1982. Las definiciones de Sabato son equivalentes, por otra parte, a las del folleto precitado del CELS (1982, p. 20), que ejemplifica, en general, la alegación de inocencia para los desaparecidos de los organismos, señalada por Crenzel. Sobre Sabato y los derechos humanos en el periodo dictatorial, véase Gorini (2006, p. 395-399). 
cación contrarrevolucionaria más eficaz contra el poder popular expresado por el gobierno de la Unidad Nacional vertebrado por el Justicialismo." ${ }^{49}$

La dinámica semántica entre título, subtítulo y las declaraciones sintetiza el modo en que Línea determina el estatus político -y moral- de las distintas figuras y condiciones del desaparecido. Las cadenas significantes inocencia/víctima/niñez y culpabilidad/terrorismo/adultez, reforzadas por los dichos de Sabato, sugieren la identificación de los desaparecidos (adultos) con los "terroristas", determinan que la revista los señale como desestabilizadores democráticos y, por ello, sea menos terminante en la condena a su supresión ilegal. Conforme parece alentar la postura particular de Sabato, la aparición con vida de los desaparecidos infantiles debe componer el reclamo fundamental. De alguna manera, estos niños aparecerían representando -seguimos a Franco (2015, p. 66) - a toda la sociedad, atrapados en el fuego cruzado de la "matriz binaria" de los extremismos. ${ }^{50}$

Por otra parte, estas modalidades referenciales del "terrorismo", la represión y las "víctimas inocentes" también integraban el discurso sobre los derechos humanos de las fuerzas políticas de la Multipartidaria, entre ellas la de un justicialismo atravesado por su pasado reciente y renuente a su revisión crítica. ${ }^{51}$

Con el fin del conflicto por las islas Malvinas, en junio de 1982, sobrevendría el colapso de la dictadura. El año y medio posterior avizora el crecimiento de la movilización política opositora y su presión para condicionar los términos de su retirada del poder (Canelo, 2008, pp. 194-204; Novaro y Palermo, 2003, pp. 461 y ss.). La reactivación partidaria tiene como efecto indirecto la desarticulación de la Multipartidaria y el retorno de la competencia política a partir de la expectativa de una inminente convocatoria a comicios presidenciales, concretados en octubre de 1983. Por su parte, Línea vuelca su apoyo al PJ y su fórmula de Ítalo Luder y Deolindo Bittel. En tal sentido, si bien los derechos humanos estaban ocupando un lugar importante en el discurso del candidato de la UCR, Raúl Alfonsín (Aboy Carlés, 2001; Gorini, 2006, pp. 598604), mientras crecía la movilización de los organismos, el de las Madres de

49 “Los niños siempre son inocentes”, Línea, núm. 18, enero de 1982, pp. 10-11.

50 "Por eso, junto a nuestro repudio a la acción del terrorismo, queremos contribuir a que aparezcan y sean devueltos los niños que -sean o no los hijos de delincuentes- son sin duda niños argentinos e inocentes de toda culpa.” Sabato en Gorini (2006, pp. 395-399).

${ }^{51}$ Véase declaración "Antes que sea tarde", del 10 de diciembre de 1981. En La propuesta de la Multipartidaria (1982, pp. 161-184); Crenzel (2010, p. 79); Franco (2015, p. 59). 
Plaza de Mayo en especial, no ocurría lo mismo en el caso del justicialismo. Inmersa en la campaña, Línea llega a afirmar que el realce público-mediático del tema respondía a una iniciativa del poder dominante en retirada, para distraer a la sociedad de las realidades socioeconómicas impuestas. Pasando, por ende, de las insinuaciones de su instrumentalización por "agentes" internacionales ligados al terrorismo a una conspirativa "cortina de humo" del establishment, que ofrecía a las fuerzas armadas de chivo expiatorio de la represión para asegurar sus intereses. ${ }^{52}$ Luder, indagado en un reportaje de la revista sobre la "lucha entre la subversión y la represión", contestaba que debía encauzarse por el Estado de Derecho, evitándose los "mecanismos de excepción" y brindando "seguridad jurídica" a la población, sin pronunciarse sobre los reclamos de información y justicia de los organismos de derechos humanos y de los familiares de las víctimas, en ostensible diferencia con Alfonsín. ${ }^{53}$ Las vagas definiciones partidarias delineaban consiguientemente cierta indulgencia con los perpetradores y una tenue promesa de justicia para las víctimas. Subyacía, por lo demás, y como se afirmara, una relativa desatención a los derechos humanos dentro de la programática de campaña. Acaso por desalentar cualquier revisión eventual de la actuación represiva previa a 1976, sistematizada a partir del decreto de "aniquilación del accionar subversivo" rubricado por Luder como presidente provisional en 1975, aún bajo gobierno constitucional, y que incluso era esgrimido por las fuerzas armadas para justificar su faena desde entonces (al respecto, véase Franco, 2012; 2018). Podían incidir del mismo modo las promesas de enjuiciamiento e investigaciones de Alfonsín -miembro, a la sazón, de la Asamblea Permanente

52 “La 'democracia' que viene...”, Línea, núm. 25, julio de 1982, pp. 16-17.

${ }^{53}$ Entrecomillados textuales en "La juventud dialoga con Luder", Línea, núm. 45, agosto de 1983, pp. 15-16 y 22-23. El candidato se pronunció inicialmente por convalidar la ley de facto de autoamnistía, promulgada en septiembre de 1983, que aseguraba impunidad a las fuerzas armadas en lo tocante a la represión. Esta aseveración, tan recordada en la bibliografía posterior, no implicó que más adelante se mostrara contrario a dicha norma. Véase Franco (2014, pp. 4-5). Respecto a su rechazo en la propia revista, véase "Luder responde", Línea, núm. 46, septiembre de 1983, p. 2. Un artículo previo de Línea culpaba a la cúpula castrense por un diseño represivo que ponía al margen de la ley a los mandos medios y bajos y los responsabilizaba por órdenes emanadas de la superioridad. Este argumento, que orientaba las culpabilidades en sentido ascendente en procura de no condenar en bloque a la institución militar, aparece similarmente en las declaraciones de campaña de Alfonsín sobre el enjuiciamiento de los represores y conformaría el nudo sustancial de la Ley de Obediencia Debida, aprobada en 1987, durante el régimen democrático y bajo presión castrense. Véase "La crisis militar", Línea, núm. 38, abril de 1983, pp.16-18; sobre la postura de Alfonsín, véase Aboy Carlés (2001, pp. 175-178). 
por los Derechos Humanos (APDH)-, que incluían acusaciones de colusión del peronismo y del sindicalismo con las autoridades de facto (que bautizaría como un "pacto-militar sindical") (Aboy Carlés, 2001, p. 174).

Asimismo, el humor gráfico que publica regularmente la revista en los meses finales de la dictadura muestra la tematización ocasional de las desapariciones forzadas. Un chiste de Beas satiriza las versiones sobre la difusión oficial de listas de desaparecidos, exigida reiteradamente por el movimiento de derechos humanos. Su trama asemeja la condición de las víctimas a la truculencia de los rumores sobre la existencia de tales listados y la consiguiente posibilidad de su difusión oficial (véase imagen 4). Otro chiste posterior retoma el tópico de las listas, esta vez en torno a la presunción de su extensa cuantía (véase imagen 5). Ambos chistes, por lo demás, cobran relieve en función de la presencia de la cuestión de las listas en la agenda mediática, en tanto las notas con las que comparten espacio no la mencionan en absoluto.

\section{EXCURSUS: EL NUNCA MÁS ANTES DEL NUNCA MÁS}

No es este el sitio para reseñar la historia de la CoNADEP, creada en 1984 por disposición del nuevo gobierno constitucional para investigar las violaciones a los derechos humanos y abordada en destacados trabajos recientes (Crenzel, 2008; Franco, 2015). El producto más conocido de su labor sería el informe Nunca Más, condensado y publicado en la forma de libro, cuyo título se convertiría en consigna asociada a la lucha por los derechos humanos en Argentina. Su etimología ha sido relacionada con dos personalidades componentes de la Comisión, la periodista Magdalena Ruiz Guiñazú y el rabino Marshall Meyer, y fue fechada hacia el inicio de sus actividades (Crenzel, 2008, p. 81; para la atribución a Meyer, Rosemberg, 2010, p. 160).

Sin embargo, Línea suministra un claro antecedente alternativo de uso público del lema en una portada con similar connotación emblemática; es decir, con intención de condensar y estabilizar una significación sobre el pasado (Feld, 2009, p. 100), pero inscrita en el discurso político coyuntural. En ella se sintetizan componentes estereotipados del atuendo militar, combinados con los atribuidos al exministro Martínez de Hoz, símbolo de las políticas neoliberales de la dictadura. La bota de caña alta -ya empleada en otra portada para simbolizar la opresión castrense- y la gorra de uniforme aparecen unidas a las grandes orejas omnipresentes en toda caricatura del funcionario -es- 

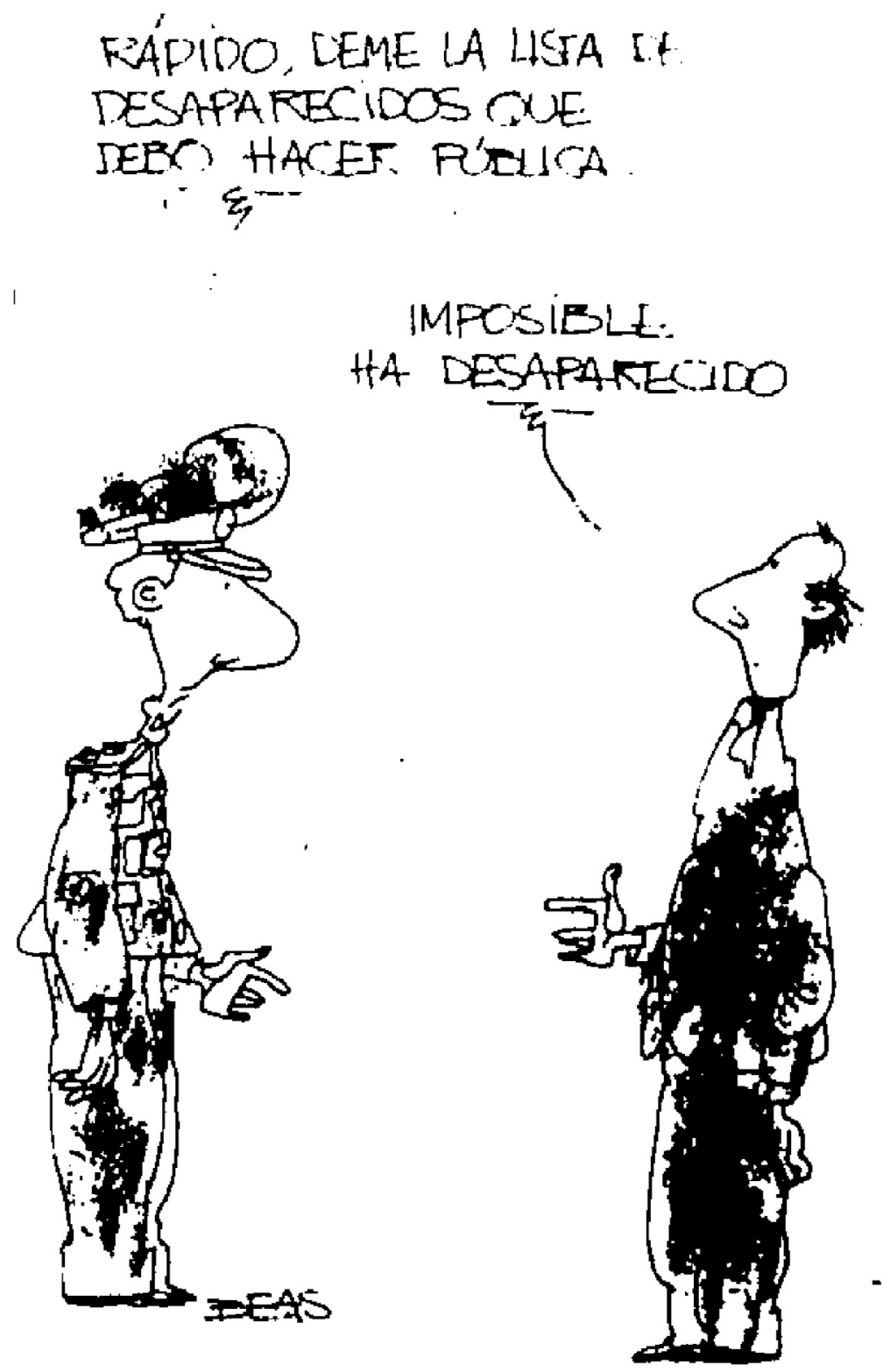

Imagen 4. Chiste de Beas. Línea, núm. 36, marzo de 1983, p. 13. 


\section{SEGUIDAMENTE DAREMOS} LECTURA A LA LISTA DE DESAPARECIDOS...

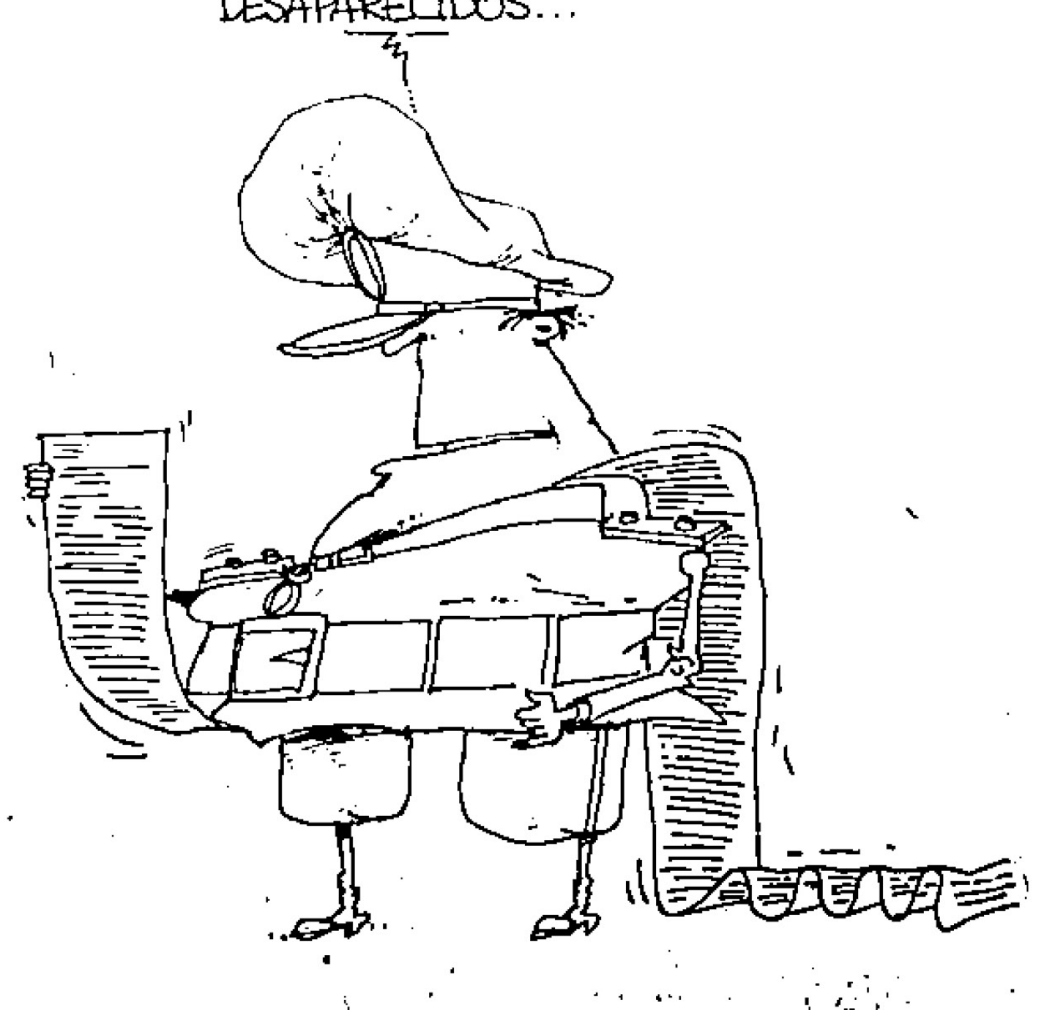

Imagen 5. Anónimo. Línea, núm. 41, junio de 1983, p. 30.

tandarizada a partir de su representación en otras publicaciones contemporáneas, como la célebre Humor-. ${ }^{54} \mathrm{El}$ anclaje imagético lo constituye el titular en tipografía catástrofe "Nunca más", con intenciones admonitorias evidentes.

${ }^{54}$ Por la representación de Martínez de Hoz, cotéjense las tapas de Humor, núm. 1, junio de 1978; núm. 15, julio de 1979; núm. 46, octubre de 1980; núm. 74, enero de 1982, entre otras, e incontables chistes gráficos en la misma publicación y periodo, más la representación, de 


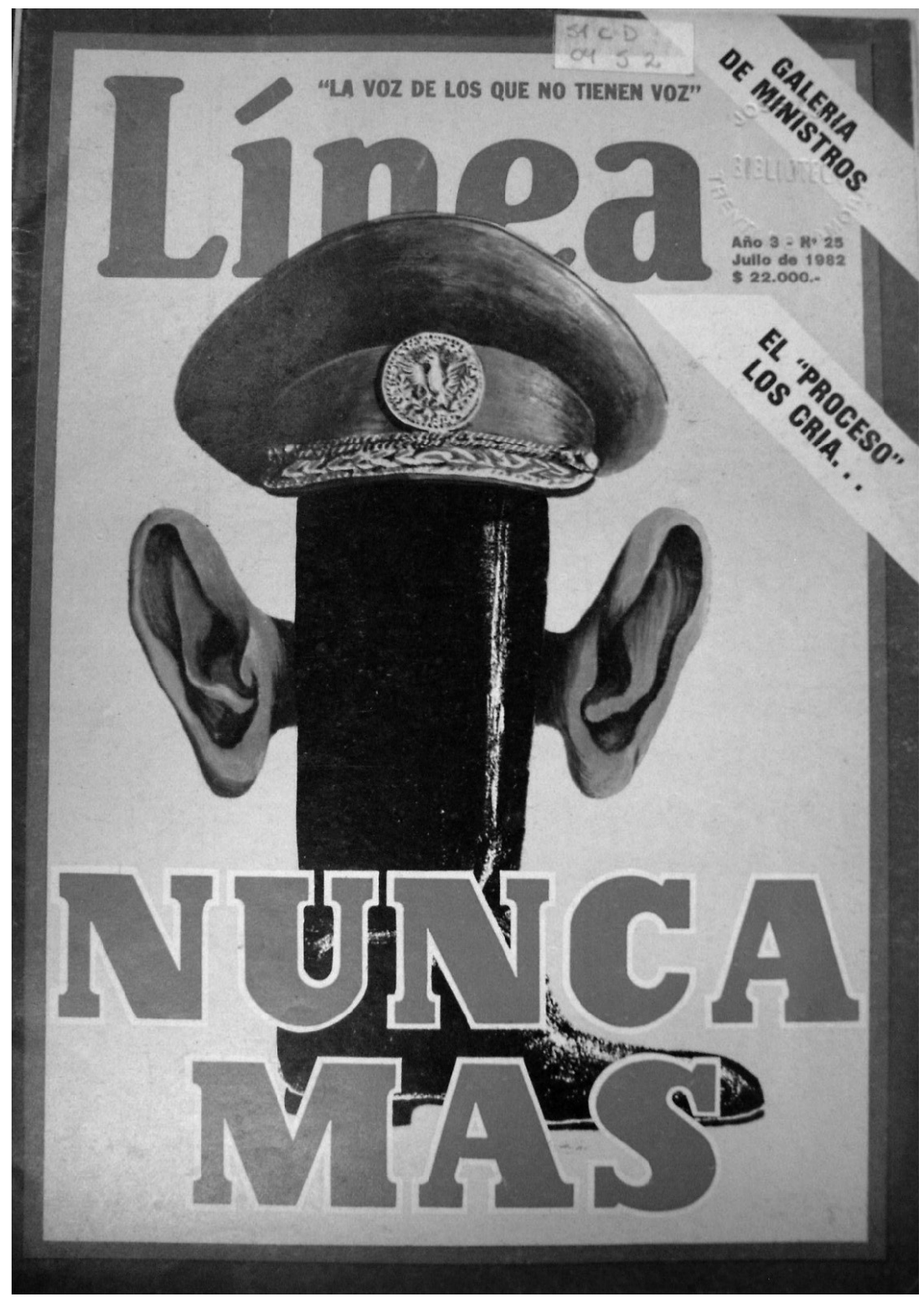

Imagen 6. Portada. Línea, núm. 25, julio de 1982. 
Inmersa en la posguerra de las Malvinas, la edición convoca mediante esta figuración peyorativa del poder dictatorial a su finalización inmediata. La nota que le daba motivo advertía sobre un posible tránsito a un régimen democrático condicionado e instaba a la unificación del peronismo como eje político opositor, de cara al proceso electoral..$^{55}$ La labor de la CONADEP y su producto editorial posterior harán perdurar el sentido a ellos asociado de la consigna. Corresponde, empero, destacar esta precursora aparición de posible influencia en su decurso semántico posterior.

\section{CONCLUSIONES}

Como expresión mediática, Línea surge en 1980 para contender un escenario signado por los coletazos finales de la represión estatal, de la desestructuración social y, a la vez, de la crisis del régimen cívico-militar que las había llevado adelante como objetivos programáticos centrales. Se volvería, con el tiempo, una de las publicaciones más caracterizadas - entre una oferta escasadel campo opositor en resguardo de la herencia política, social y cultural peronista. Tal encuadre ideológico, como hemos visto, la volvió cautelosa frente al movimiento de defensa de derechos humanos, de creciente protagonismo disidente para la fecha de su surgimiento. Dicha desconfianza reflejaba la sospecha por la aparente asistencia de los organismos al actor "subversivo", en espejo de similares aprehensiones partidarias. Si bien el peronismo había registrado una notoria cantidad de víctimas por la represión, la filiación progresista e izquierdista mayoritaria asociada a estas, ajena a la postura de Línea, y los antecedentes represivos de los gobiernos justicialistas entre 1974 y 1976 que defendía, condicionaban su percepción, por fuera de declaraciones episódicas -una de ellas, sin embargo, muy significativa-e intervenciones individuales.

Tal tensión es encauzada en el marco de la polarización global de la guerra fría que atraviesa a los actores políticos -incluida la dictadura-, en torno del desarrollo ideológico peronista y de su doctrina de la Tercera Posición. Línea aparece interesada, empero, en las demandas del movimiento por su

estilo realista, en la tapa de Línea, núm. 3, agosto de 1980. Asimismo, en la tapa de un número posterior, una bota castrense ilustra la leyenda en grandes titulares "Argentina ocupada", Línea, núm. 16, noviembre de 1981.

${ }_{55}$ "La 'democracia' que viene...", Línea, núm. 25, julio de 1982, pp. 16-17. 
potencial crítico del régimen imperante. Su construcción ideológica en medio de bloques, le sirve como criterio para cuestionar a los golpistas y denunciar al activismo armado izquierdista como un extremismo, en pos de la defensa de la institucionalidad republicano-democrática, y de erigir al movimiento peronista como custodio natural de los derechos fundamentales de las masas. La dictadura resultaría, entonces, de la perversión funcional de unas fuerzas armadas convertidas en "partido militar", comprometido con intereses foráneos. A su vez, el carácter criminal de la "subversión" habría coadyuvado a dicha irrupción castrense.

Por otra parte, los nexos con sectores eclesiásticos de la revista aproximan su discurso crítico al de algunos prelados en torno a las violaciones de los derechos humanos; este encuadre, sumado a las repercusiones internacionales de la distinción a un dirigente cristiano como Pérez Esquivel, fundamentan su entrevista al Nobel. El diálogo entre partes desde la revista mantendría, sin embargo, los prejuicios de su inscripción y experiencia política, con el "resultado" de la actitud defensiva del reporteado y de las insinuaciones de Línea a los derechos humanos como práctica teñida de parcialidad política. Su fondo argumentativo recurrirá, también en esta instancia, a condenar la represión de la dictadura, a legitimar la ejercida por el gobierno constitucional justicialista derrocado y a censurar la "subversión" desestabilizadora del último, para desmarcar su postura opositora $-y$ su atención circunstancial a los derechos humanos- de vinculaciones que dieran motivos a su persecución por las autoridades. En suma, para Línea, la "pacificación" con base en la justicia promovida por el Nobel podía esconder, como para el resto de los organismos, una voluntad de "revancha" de los insurgentes derrotados, con apoyo extranjero. Una visión del movimiento, por lo demás y desde este sesgo conspirativo, bastante cercana a la de la "campaña antiargentina" de la Junta gobernante (Jensen, 2012).

La aparición del Movimiento Nacional por los Niños Desaparecidos motiva, con el precedente de las opiniones del historiador Ferla, que la revista vuelva sobre la culpabilidad y la inocencia de los desaparecidos. Para ello se apoya en los argumentos de un ubicuo intelectual integrante de la flamante entidad, Ernesto Sabato, para constituir la figura del niño desaparecido en prototipo de una "inocencia" absoluta. Esta presentación discursiva coyuntural de los organismos de derechos humanos sobre las responsabilidades de los desaparecidos, extremada para los casos infantiles, hizo subrayar a la revista que las de los adultos en particular podían llevar a contemplar su condición 
de víctimas en un segundo plano. Estas definiciones guardaban vasos comunicantes con la concepción de los "dos demonios" posdictatoriales, plasmada posteriormente por Sabato en el prólogo del Nunca más. Queda como nota de época, además, la anticipación en Línea de este último eslogan, inadvertida hasta hoy en las memorias de la lucha por los derechos humanos del periodo.

La manera en que Línea tematizaba la cuestión reflejaba, en definitiva, sus prevenciones ante una modalidad de reclamo y organización ajena a su tradición política generada ante la virulencia de la represión ilegal sistematizada de Estado, y potenciada con la erosión paulatina del esquema de poder de la dictadura. Con el caso testigo, de una heterogeneidad inédita pero ignorada por la revista, de unas madres desplegadas en el ámbito público en reclamo del paradero de sus hijos -mientras que el activismo cristiano de Pérez Esquivel, legitimado por el premio Nobel, le resultaba más comprensible- ${ }^{56}$ Ello también se vería reflejado frente a la campaña presidencial de 1983, que prometía la restauración del orden republicano democrático. Inmersa en la compulsa, Línea daría testimonio de la minimización del tema en las declaraciones del PJ, acorde con su posicionamiento moderado ante las fuerzas armadas, a las suspicacias descritas sobre los organismos y a su cautela ante las posibilidades de revisión de un pasado reciente que incluía sus propias gestiones de gobierno.

\section{LISTA DE REFERENCIAS}

Aboy Carlés, G. (2001). Las dos fronteras de la democracia. La reformulación de las identidades políticas de Alfonsín a Menem. Rosario: Homo Sapiens.

Arfuch, L. (1995). La entrevista: una invención dialógica. Buenos Aires: Paidós.

Armony, A. (1999). La Argentina, los Estados Unidos y la cruzada anticomunista en América Central, 1977-1984. Quilmes: UNQ.

Besoky, J. L. (2013). La derecha peronista en perspectiva. Nuevo Mundo Mundos Nuevos. Recuperado de: https://journals.openedition.org/nuevomundo/65374

Blaustein, E. y Zulueta, M. (1998). Decíamos ayer. La prensa argentina bajo el Proceso. Buenos Aires: Colihue.

${ }^{56}$ Sobre el origen y trayectoria de Madres de Plaza de Mayo en la dictadura, véase en particular Gorini (2006). 
Borrelli, M. y Raíces, E. (2018). "Que se vayan”. La revista peronista Línea frente a la dictadura militar a través de sus tapas y contratapas (1980-1982). La Trama de la Comunicación, 22(2), 97-123. Recuperado de https://latrama.fcpolit.unr.edu.ar/ index.php/trama/article/view/662

CAdHu (2014). Argentina: Proceso al genocidio. Buenos Aires: Colihue

Calveiro, P. (2004). Poder y desaparición. Buenos Aires: Colihue.

Canelo, P. (2008). El proceso en su laberinto: la interna militar de Videla a Bignone. Buenos Aires: Prometeo.

CELS (1982). Los niños desaparecidos. Buenos Aires: Autor.

ConAdep (1985). Nunca Más. Informe de la Comisión Nacional sobre Desaparición de Personas. Buenos Aires: Eudeba.

Crenzel, E. (2008). La historia política del Nunca Más. Buenos Aires: Siglo XXI.

Crenzel, E. (2010). La víctima inocente: de la lucha antidictatorial al relato del Nunca Más. En E. Crenzel (coord.), Los desaparecidos en la Argentina. Memoria, representaciones e ideas (1983-2008) (pp. 65-83). Biblos: Buenos Aires.

Devoto, F. y Pagano, M. (2009). Historia de la historiografía argentina. Buenos Aires: Sudamericana.

Feld, C. (2009). "Aquellos ojos que contemplaron el límite". La puesta en escena televisiva de testimonios sobre la desaparición. En C. Feld y J. Stites Mor (comps.), El pasado que miramos. Memoria e imagen ante la historia reciente (pp. 77-109). Buenos Aires: Paidós.

Franco, M. (2012). Un enemigo para la nación. Orden interno, violencia y subversión, 19731976. Buenos Aires: FCE.

Franco, M. (2014). El complejo escenario de la disolución del poder militar en la Argentina: la autoamnistía de 1983. Contenciosa, 2, 1-18. Recuperado de http://www. contenciosa.org/Sitio/VerArticulo.aspx?i=13

Franco, M. (2015). La "teoría de los dos demonios" en la primera etapa de la posdictadura. En C. Feld y M. Franco (dirs.), Democracia, hora cero: actores, políticas y debates en los inicios de la posdictadura (pp. 23-79). Buenos Aires: FCE.

Franco, M. (2018). El final del silencio. Dictadura, sociedad y derechos humanos en la transición (Argentina, 1979-1983). Buenos Aires: FCE.

Ghío, J. M. (2007). La Iglesia en la política argentina. Buenos Aires: Prometeo.

González Bombal, I. (1991). El diálogo político: la transición que no fue. Buenos Aires: CEDES.

Gorini, U. (2006). La rebelión de las Madres. Historia de las Madres de Plaza de Mayo. Tomo I (1976-1983). Buenos Aires: Norma.

Homenaje a Adolfo Pérez Esquivel (1980). Buenos Aires: APDH. 
Iribarne, A. (comp.) (2006). Letras contra el miedo: documentos del peronismo durante la dictadura (1976-1983). Buenos Aires: CS editor/Fundación El Calafate.

Jauretche, A. (1973). Manual de zonceras argentinas. Buenos Aires: Peña Lillo.

Jensen, S. (2012). Los exiliados. La lucha por los derechos humanos durante la dictadura. Buenos Aires: Sudamericana.

La propuesta de la Multipartidaria (1982). Buenos Aires: El Cid editor.

Leñero, V. y Marín, C. (1986). Manual de periodismo. México: Grijalbo.

Manson, E. (2008). José María Rosa. El historiador del pueblo. Buenos Aires: Ciccus

Neiburg, F. (1998). Los intelectuales y la invención del peronismo. Buenos Aires: Alianza.

Novaro, M. y Palermo, V. (2003). La dictadura militar, 1976-1983. Buenos Aires: Paidós.

Paradiso, J. (2002). Vicisitudes de una política exterior independiente. En J. C. Torre (dir.), Nueva historia argentina: Los años peronistas (1943-1955) (T. 8, pp. 523-572). Buenos Aires: Sudamericana.

Raíces, E. (2012). Ante "un acto de locura patriótica". La revista Línea aborda el conflicto de Malvinas. Question, 1(33), 83-89. Recuperado de http://hdl.handle. net/10915/34670

Raíces, E. y Borrelli, M. (2016). Un "juego solitario”. La revista peronista Línea y el "diálogo político" durante la dictadura militar (1980-1981). Postdata, 21(2), 453-487. Recuperado de http://www.revistapostdata.com.ar/v2/wp-content/ uploads/2016/11/Ra\%C3\%ADces-y-Borrelli-1.pdf

Rosemberg, D. (2010). Marshall Meyer: el rabino que le vio la cara al diablo. Buenos Aires: Capital Intelectual.

Vicente, N. (2006). Augusto Conte, padre de la plaza. Buenos Aires: Galerna.

Yanuzzi, M. Á. (1996). Política y dictadura. Rosario: Fundación Ross. 